\title{
Phytochemical screening and antibacterial effect of root extract of B oerhaavia diffusa L. (Family Nyctaginaceae)
}

\section{Deepti M alhotra ${ }^{1}$, A mir K han $^{2}$ and F ouzia I shaq ${ }^{3 *}$}

${ }^{1}$ Department of Biotechnology, Shri Guru Ram Rai (P.G.) College, Dehradun (Uttarakhand), INDIA

${ }^{2}$ Department of Biotechnology and Biochemistry, Division of Life Science, Sardar Bhagwan Singh Post Graduate Institute of Biomedical Sciences and Research Balawala-248161, Dehradun (Uttarakhand), INDIA

${ }^{3}$ Department of Zoology and Environmental Science, Gurukul Kangri University, Haridwar (Uttarakhand), INDIA

*Corresponding author. E-mail: fouziaishaq@gmail.com and amiramu@gmail.com

Received: April 01, 2013; Revised received:May 22, 2013; Accepted: J une 07, 2013

\begin{abstract}
B oerhaavia diffusa belonging to the family of the Nyctaginaceae is mainly a diffused perennial herbaceous creeping weed of India. The present study deals with the investigation of phytochemical analysis and evaluation of the antimicrobial activity of the aqueous and methanolic extract of the roots of Boerhaavia diffusa. The result revealed the presence of alkaloid, glycoside, saponins, flavonoids, polysaccharides, steroid and tannin in both the root extracts. B. diffusa root extract possesses antimicrobial activity as the zone of inhibition was observed for both gram positive as well as gram negative bacterial strains.
\end{abstract}

Keywords: Alkaloid, Antimicrobial activity, Boerhaavia diffusa, Flavonoids, Phytochemical

\section{INTRODUCTION}

Boerhaavia diffusa L. (Nyctaginaceae) is a perennial herbaceous plant growing in tropical regions such as the Antilles, South America, India and Africa (Meena et al., 2010). It is used in ayurvedic medicine system to treat various health problems. One of the most typical exemplary plants of the ayurvedic medicine is Boerhaavia diffusa Linn (Rastogi and Mehrotra, 1993; Akhilesh et al., 1999). Boerhaavia diffusa (Spreading Hogweed in English), belongs to the family of the Nyctaginaceae, is mainly a diffused perennial herbaceous creeping weed of India (Punarnava in Hindi) and of Brazil (known as Erva tostão). The plant was named in honor of Hermann Boerhaave, a famous Dutch physician of the 18th century (Mahesh et al., 2012). B. diffusa is up to $1 \mathrm{~m}$ long or more, having spreading branches. The stem is prostrate, woody or succulent, cylindrical, often purplish, hairy, and thickened at its nodes. The leaves are simple, thick, fleshy, and hairy, arranged in unequal pairs, green and glabrous above and usually white underneath. The shape of the leaves varies considerably ovate - oblong, round, or subcordate at the base and smooth above (Kirtikar and Basu, 1956). Six species are reported in India. This trailing herb is mainly collected after rainy season in India (Ayurvedic Pharmacopoeia of India, 2005). The whole plant analysis of $B$. diffusa is known to contain numerous phytochemicals constituents that include flavonoids, alkaloids, triterpenoids, steroids, lipids, lignins, tannins, phlobaphenes and ursolic acid (Jones and Ennist, 1983; Jain and Singh, 1994; Lamela et al., 1985). The root is mainly used to treat gonorrhea, internal inflammation of all kinds, dyspepsia, edema, jaundice, menstrual disorders, anemia, liver, gall bladder and kidney disorders, enlargement of spleen, abdominal pain, abdominal tumours, and cancers, diuretic documented in Indian Pharmacopoeia, digestive aid, laxative and a menstrual promoter (Ramachandra et al., 2012). Traditionally, this plant has been extensively used in the treatment of dyspepsia, jaundice, enlargement of liver, abdominal pain and as antistress agent (Awasthi and Verma, 2006). The whole plant, specifically the roots have been screened to possess adoptogenic, antistress, antidiabetic and immunopotentiator activity and as antioxidant in different models (Sumanth and Mustafa, 2007). This plant has proved to be beneficial in the treatment of abdominal cancers and tumours. Studies have also shown that leaves have various nutritive components like Calcium, Sodium and Vitamin C due to which it can be included as an effective component of the diet (Rajpoot and Mishra, 2011). Despite the wide therapeutically use of B. diffusa, there are still no scientific data in the literature which clearly (i) demonstrate the existence of an antimicrobial activity and (ii) explain the mechanism of its action (Ramachandra et al., 2012). Since B. diffusa is largely used in ayurveda medicine and the scientific data that explain such use are deficient, the purpose of our study was to investigate the 
phytochemical constituents of B. diffusa and to evaluate the antimicrobial activity of the aqueous and methanolic extract of the roots of $B$. diffusa.

\section{MATERIALS AND METHODS}

Plant material: The roots of Boerhaavia diffusa were collected in September 2011 from local trader, Dehradun (Uttarakhand) and specimen was identified and authenticated at the Botanical Survey of India, Northern Zone, Dehradun with Accession No. 114549 and a sample deposited in the herbarium of BSI, Dehradun, U.K. All the chemicals used for phytochemical analysis were of analytical grade.

Preparation of the extract: The plant root materials were thoroughly washed, shade dried till a constant weight of sample obtained and then powdered mechanically using a blender. $100 \mathrm{~g}$ of powdered material was soaked in $100 \mathrm{ml}$ of aqueous and methanol medium separately for 72 hours. It was filtered by using Whatman no.1 filter paper. The solvent was distilled out completely from the filtrate under the reduction pressure in Rota vapor (Kaur and Goel, 2009) and the weight of extract was measured.

Test microorganisms: Authentic pure cultures of bacterial strains- Bacillus subtilis, Escherichia coli, Klebsiella pneumonia, Staphylococcus aureus and Streptococcus sps were obtained from Department of Microbiology, Shri Mahant Indresh Hospital, Dehradun, India.

Pharmacognostic study: Macroscopic and microscopic examination was done as per the guidelines of Ayurvedic Pharmacopoeia of India (2005).

Phytochemical scr eening

The preliminary phytochemical analysis of aqueous and methanol extracts was carried out using the standard methods described by Sazada et al., 2009, Harborne, 2005, Trease and Evans, 1989.

Alkaloids-Tannic A cid Test: In the extract solution few drops of $10 \%$ tannic acid solution was added, buff precipitate was formed, and it conferred the presence of alkaloids.

Glycoside- K eller K illiani Test: Dissolve the extract in acetic acid containing traces of ferric chloride and transfer to a test tube containing sulphuric acid. At the junction, formation of a reddish brown colour, which gradually becomes blue, confirms the presence of glycosides.

Flavonoids - Alkaline R eagent Test: extract solution when treated with sodium hydroxide solution gives yellow or red color immediately.

Tannins- Vanillin Hydrochloride Test: extract solution when treated with few drops of Vanillin hydrochloride reagent gives purple color.

Saponins- Froth Test: place $1 \mathrm{ml}$ extract solution in a measuring cylinder. Make up the volume to $20 \mathrm{ml}$ using distill water. Shake for a minute. Presence of froth on top confirms presence of saponins.

Proteins-Ninhydrin Test: Add two drops of freshly prepared $0.2 \%$ Ninhydrin reagent to the extract solution and heat. Development of blue colour reveals the presence of proteins, peptides or amino acids.

Carbohydrates-M olisch test: To $2 \mathrm{ml}$ of the extract, add $1 \mathrm{ml}$ of á-naphthol solution, and concentrated sulfuric acid through the sides of test tube. Purple or reddish violet color at the junction of the two liquids reveals the presence of carbohydrates.

Q uinines-Sulfuric Acid test: To $2 \mathrm{ml}$ of test solution, 1 $\mathrm{ml}$ of conc. Sulphuric acid was added and was allowed to stand undisturbed for some time. Development of red color shows presence of quinines.

Phenols-F erric Chloride test: extract solution gives bluegreen color with few drops of ferric chloride.

G um and M ucilage- $10 \mathrm{ml}$ extract added slowly to $25 \mathrm{ml}$ absolute alcohol with constant stirring. Presence of precipitate confirms gum and mucilage.

Ster oids-L iber mann-B urchard test: $1 \mathrm{~g}$ extract dissolved in few drops of chloroform, $3 \mathrm{ml}$ acetic anhydride and $3 \mathrm{ml}$ glacial acetic acid. Drops of conc. $\mathrm{H}_{2} \mathrm{SO}_{4}$ added along the side of test tube. Appearance of Bluish-green color confirms steroids.

Lipid-Stain test: Press small amount of extract between two filter papers. Stain on filter paper one indicates presences of fats or lipids.

Determination of zones of inhibition by well diffusion method: Methanol and aqueous root extract of Boerhaavia diffusa was prepared in sterile test tubes. Pure Kanamycin $(50 \mu \mathrm{l})$ as a standard antibiotic for comparison of the results was taken. The extracts and standard drugs were dissolved in Dimethyl Sulphoxide (DMSO). Sterile nutrient agar plates were prepared and incubated at $37{ }^{\circ} \mathrm{C}$ for 24 hours to check for any sort of contamination. The sterile nutrient agar medium in petridishes was uniformly smeared with test culture through pour plating technique. Well $(5 \mathrm{~mm})$ were made in each petridish to which 30 il of solvent extracts were added. For each treatment three replicates were maintained. Methanol and distilled water served as control for respective solvent extract. The petridishes were incubated at $37^{\circ} \mathrm{C}$ for 24 hours and the diameters of zone of inhibition measured in $\mathrm{mm}$. Similar procedure was adopted for the pure kanamycin and the corresponding zone of diameters was compared accordingly (Satish et al., 1999).

\section{RESULTS AND DISCUSSION}

The constant weight of dried plant root material out of $1000 \mathrm{~g}$ was obtained as $960 \mathrm{~g}(96 \%)$.

M acroscopic: White bitter tasting powder with a characteristic odour.

M icroscopic: The powder showed characters like cork 
Table 1. Successive extraction of B. diffusa root.

\begin{tabular}{|c|c|c|c|c|c|c|}
\hline Solvent & $\begin{array}{l}\text { Weight of initial } \\
\text { root powder used }\end{array}$ & W eight of ex & act & $\begin{array}{l}\text { Extractive } \\
\text { value }(\%)\end{array}$ & Color & Appearance \\
\hline Aqueous & $100 \mathrm{~g}$ & $10.5 \mathrm{~g}$ & & $10.5 \%$ & Dark brown & Sticky \\
\hline Methanol & $100 \mathrm{~g}$ & $8.45 \mathrm{~g}$ & & $8.45 \%$ & Light brown & Non-sticky \\
\hline \multirow{10}{*}{\multicolumn{3}{|c|}{$\begin{array}{l}\text { cells in surface view, acicular crystals and prismatic } \\
\text { crystals of calcium oxalate, thin long narrow fibers with } \\
\text { sharp pointed ends and narrow lumen, simple to } \\
\text { compound oval to rounded starch grains were also } \\
\text { observed, simple pitted vessels and few parenchyma with } \\
\text { starch grains also seen. } \\
\text { Extractive value: Successive extraction of B. diffusa root } \\
\text { gave extractive values of } 10.5 \text { and } 8.45 \text { for aqueous and } \\
\text { methanol extract respectively as shown in Table } 1 \text {. } \\
\text { Phytochemical results: Preliminary phytochemical } \\
\text { results showed the presence or absence of certain } \\
\text { phytochemicals in B. diffusa. The tests performed using }\end{array}$}} & \multicolumn{4}{|c|}{ Table 3. Physico-chemical parameters of B. diffusa. } \\
\hline & & & \multicolumn{3}{|c|}{ Parameters } & Results \\
\hline & & & \multicolumn{3}{|c|}{ Description } & Light brown \\
\hline & & & \multicolumn{3}{|c|}{ Foreign matter } & $<1.1 \%$ \\
\hline & & & \multicolumn{3}{|c|}{$\mathrm{pH}$} & 5.79 \\
\hline & & & \multicolumn{3}{|c|}{ Loss on drying } & $3.00 \% \mathrm{w} / \mathrm{w}$ \\
\hline & & & \multicolumn{3}{|c|}{ Total ash } & $8.45 \% \mathrm{w} / \mathrm{w}$ \\
\hline & & & \multicolumn{3}{|c|}{ Acid-insoluble ash } & $1.11 \% \mathrm{w} / \mathrm{w}$ \\
\hline & & & \multicolumn{3}{|c|}{ Water-soluble ash } & $15.10 \% \mathrm{w} / \mathrm{w}$ \\
\hline & & & \multicolumn{3}{|c|}{ Alcohol-soluble ash } & $12.33 \% \mathrm{w} / \mathrm{w}$ \\
\hline
\end{tabular}
revealed the presence of alkaloid, glycoside, saponins, flavonoids, polysaccharides, steroid and tannin while absence of gum, mucilage, quinines and results are given in Table 2.

The B. diffusa plant contains a large number of such compounds as flavonoids (Pandey et al., 2005), quercitin derivatives and alkaloids (Pereira et al., 2009), lipids, steroids, carbohydrates, proteins, and glycoproteins (Khalid et al., 2011; Khandelwal, 2002). Punarnavine boeravinones namely Boerhavinone A, Boerhavinone B, Boerhavinone C, Boerhavinone D, Boerhavinone $\mathrm{E}$ and Boerhavinone F (Chaudhary and Dantu, 2011; Lami et al., 1991), hypoxanthine, punarnavoside (Jain and Khanna, 1989), have been isolated and studied in detail

Table 2. Phytochemical detection of components in B. diffusa root extracts.

\begin{tabular}{lcc}
\hline Test & \multicolumn{2}{c}{ Root part } \\
\cline { 2 - 3 } & $\begin{array}{c}\text { Aqueous } \\
\text { extract }\end{array}$ & $\begin{array}{c}\text { M ethanol } \\
\text { extract }\end{array}$ \\
\hline Alkaloids & + & + \\
Glycoside & + & + \\
Flavinoids & + & + \\
Tannins & + & + \\
Saponins & + & + \\
Proteins & + & + \\
Carbohydrates & + & + \\
Quinines & - & - \\
Phenols & + & + \\
Gum & - & - \\
Mucilage & - & - \\
Steroids & + & + \\
Lipid & + & + \\
\hline
\end{tabular}

for their biological activity. Kokate et al., 2005 has reported presence of $6 \%$ potassium nitrate and urosolic acid in roots of $B$. diffusa. The roots have been reported to contain alkaloids (punarnavine), rotenoids (boeravinones), flavonoids, amino acids, ligans (liriodendrons), $B$ sitosterols, and tetracosanoic, esacosanoic, stearic and ursolic acids (Ujowundu et al., 2008). These results support our result for presence of various phytoconstituents in $B$. diffusa roots.

Physico-chemical parameters: Physico-chemical parameters of B. diffusa are tabulated in Table.3. The results are in accordance to the Ayurvedic Pharmacopoeia of India.

A ntibacterial activity: The antibacterial activity of root extracts of $B$. diffusa for few bacterial strains is presented in Table 4 . The results clearly depicted that B. diffusa root extract has antimicrobial activity. The zone of inhibition was observed for both gram positive as well as gram negative bacterial strains that were Bacillus subtilis, Escherichia coli, Klebsiella pneumonia, Staphylococcus aureus and Streptococcus. The methanolic extract of $B$. diffusa was observed to have comparatively more effect than aqueous extract. All the five bacterial strain had inhibited growth in methanolic extract while in aqueous extract four bacterial strains had inhibited growth. In vitro antimicrobial activity of methanol extract was significantly more on gram positive bacterial strains than gram negative ones. However aqueous extract of $B$. diffusa roots had almost equal inhibitory property on bacterial strains. Methanolic extract had maximum inhibition for $\mathrm{S}$. aureus $(17.5 \mathrm{~mm})$ and least for E.coli $(8.5 \mathrm{~mm})$.The methanolic extract of B. diffusa showed significant antimicrobial activity with the zone of inhibition lying in the range of $8 \mathrm{~mm}$ to $18 \mathrm{~mm}$. The 
Table 4. Antibacterial activity of B. diffusa extracts.

\begin{tabular}{|c|c|c|c|c|c|c|c|}
\hline \multirow{2}{*}{$\begin{array}{l}\text { Sl. } \\
\text { No. }\end{array}$} & \multirow{2}{*}{\multicolumn{2}{|c|}{ Bacterial strains }} & \multicolumn{5}{|c|}{ Zone of inhibition (mm) } \\
\hline & & & \multirow{2}{*}{$\begin{array}{c}\text { M ethanolic } \\
\text { extract of } \\
\text { B.diffusa } \\
14.0\end{array}$} & \multirow{2}{*}{$\begin{array}{c}\text { Control for } \\
\text { methanolic } \\
\text { extract- } \\
\text { M ethanol } \\
(30 \mu \mathrm{l}) \\
\text { NIL }\end{array}$} & \multirow{2}{*}{$\begin{array}{c}\text { A queous } \\
\text { extract of } \\
\text { B. diffusa } \\
8.0\end{array}$} & $\begin{array}{c}\text { Control for } \\
\text { aqueous } \\
\text { extract- } \\
\text { distilled } \\
\text { water } \\
(30 \mu \mathrm{l}) \\
\end{array}$ & $\begin{array}{c}\text { Standard } \\
\text { antibiotic- } \\
\text { K anamycin } \\
(30 \mu \mathrm{g})\end{array}$ \\
\hline 1 & & Racillus suhtilis & & & & $\mathrm{NII}$ & 230 \\
\hline 2 & positive & Staphyloccus aureus & 17.5 & NIL & 9.0 & NIL & 24.0 \\
\hline & Bacteria & & & & & & \\
\hline 3 & Gram & Escherichia coli & 8.5 & NIL & 8.0 & NIL & 22.0 \\
\hline 4 & negative & Klebsiella pneumonia & 15.0 & NIL & 10.0 & NIL & 20.0 \\
\hline 5 & Bacteria & $\begin{array}{l}\text { Pseudomonas } \\
\text { aeruginosa }\end{array}$ & 15.6 & NIL & NIL & NIL & 20.0 \\
\hline
\end{tabular}

aqueous extract of $B$. diffusa showed significant antimicrobial activity with the zone of inhibition lying in the range of $8 \mathrm{~mm}$ to $10 \mathrm{~mm}$. Kanamycin was used as positive control as an antibacterial antibiotic which produced the inhibition zones ranging between 20 and $24 \mathrm{~mm}$. Negative control showed no formation of zone of inhibition, confirming that the inhibitory agent(s) was (were) actually from the plant extracts. The encouraging results indicate that the aqueous and methanolic root extracts of $B$. diffusa might be exploited as a natural drug for the treatment of several infectious diseases caused by these organisms and could be useful in understanding the relations between traditional cures and current medications. With this study we found that methanolic extract provides more consistent antibacterial activity. The methanolic extract of P. harmala showed strong antibacterial activity against gram positive than gram negative bacteria has been reported (Hayet et al., 2010). Various researchers have already shown that gram positive bacteria are more susceptible towards medicinal plants extracts compared to gram negative bacteria. Difference might be due to the fact that the wall in gram positive bacteria is single layered while gram negative multilayered. Phytochemical constituents analysis of B.diffusa has been proved to contain alkaloids, tannins, saponins, flavonoids, phenols etc. These compounds presence might help explain the observed antibacterial activity of $B$. diffusa root extracts. The presence of bioactive compounds has been known to show medicinal as well as some physiological activity (Krishna et al., 1997; Harbone, 2005). Abo and Ashidi (1999) have reported antimicrobial activity of pet ether, chloroform and methanol crude extracts of aerial parts, root of B. diffusa tested against both Gram positive and Gram negative bacteria by agar well method. The result revealed that the zone of inhibition of Petroleum ether extract (16.83 $\pm 0.12 \mathrm{~mm}$ ), chloroform $(13.99 \pm 0.22 \mathrm{~mm})$, methanol extract
$(19.46 \pm 0.26 \mathrm{~mm})$, the zone of inhibition is varying between $13.99 \pm 0.22 \mathrm{~mm}$ to $19.46 \pm 0.26 \mathrm{~mm}$. These data indicated that methanol crude extract of aerial part of plant exhibited strong antibacterial activity compared to petroleum ether extract. The chloroform extract of both aerial and root extract shown relatively less antibacterial activity. Ramachandra et al. (2012) has also reported invitro antibacterial potential of B.diffusa. The result revealed that methanol extract of root showed maximum activity against $S$. aureus $(17.49 \pm 0.42 \mathrm{~mm}), P$. aeruginosa $(15.61 \pm 0.42 \mathrm{~mm})$ and $K$. pneumoniae $(15.22$ $\pm 0.40 \mathrm{~mm}$ ), compared to methanol extract, the Petroleum ether and chloroform extracts showed moderate activity against $B$. subtilis $(11.53 \pm 0.46 \mathrm{~mm}, 9.11 \pm 0.40 \mathrm{~mm})$ and A. tumefaciens $(9.31 \pm 0.21 \mathrm{~mm}, 8.15 \pm 0.44 \mathrm{~mm})$ respectively. All the three extracts showed less activity against $E$. coli $(7.89 \pm 0.2 \mathrm{~mm}, 5.95 \pm 0.0 \mathrm{~mm}, 9.17 \pm 0.17 \mathrm{~mm})$ respectively. The above stated results are in accordance to the results obtained by this study.

\section{Conclusion}

Our research concludes presence of many phytoconstituents in B. diffusa root extracts which can provide various useful biological activities to this medicinal plant. The results clearly depicted that $B$. diffusa root extract has antimicrobial activity. Being naturally and widely present along with its costeffectiveness can prove as an advantage of using B. diffusa as therapeutic drug.

\section{ACK NOWLEDGEMENTS}

The author's express sincere thanks to Uttarakhand State BiotechnologyDepartment, Government of Uttarakhand. INDIA. for the financial support in the form of R \& D project to DR Amir Khan (P.I Project) bearing file no. (File No.1020/Guard-10/A.Khan/ S.B.S/R and D Project Feb, 2013). Authors also thankful to the Head of 
Biotechnology, SGRR (P.G.) College for providing research facilities and Head of Microbiology, Shri Mahant Indresh Hospital, Dehradun for providing bacterial strains.

\section{REFERENCES}

Abo, K.A. and Ashidi, J.S. (1999). Antimicrobial screening of Bridelia micrantha, Alchornea cordifolia and Boerhavia difussa. African J ournal of M edicine and M edical Sciences, 28(3-4):167-169.

Akhilesh, S; Mayank, S.S; Mishra, A; Sharma, S; Kumar A. and Bhandari, A. (1999). A Review on Thar Plants Used in Liver- Chapter in a book: Samuelsson G. Drugs of natural origin: a textbook of Pharmacognosy. 4th ed. Stockholm, Swedish Pharmaceutical Press; IJ RPC 2011, 1(2)224-236.

Awasthi, L.P. and Verma, H.N. (2006). B oerhaavia diffusa - A Wild Herb with Potent Biological and Antimicrobial Properties. http://www.asianagrihistory.org/articles/ Boerhaavia.pdf.

Ayurvedic Pharmacopoeia of India. (2005). MHFW, Deptt of AYUSH, Govt. of India, Delhi. 1(1):40.

Chaudhary, G. and Dantu, P.K. (2011). Morphological, phytochemical and pharmacological,studies on B oerhaavia diffusa L. J . Med. Plant Res.,5(3): 2125-2130.

Harborne, J.B. (2005). Phytochemical Methods. Springer (India) Pvt. Ltd., New Delhi, 17. 49-188pp.

Hayet, E; Maha, M; Mata, M; Mighri, Z; Laurent, G. and Mahjoub, A. (2010). Biological activities of Peganum harmala leaves. Afr. J . Biotechnol, .9 (48):8199-8205.

Jain, G.K. and Khanna, N.M. (1989). Punarnavoside: A new antifibrinolytic agent from Boerhaavia diffusa Linn. Indian J ournal of Chemistry, 28(B):163-166.

Jain, S.P., and Singh, S.C., (1994). Ethnomedical Botancial Survey of Ambikapur District, M.P. Ethnobiology in human welfare. Abstracts of the 4 th International Congress of Ethnobiology, Lucknow, Uttar Pradesh, India, 17th-21 ${ }^{\text {st }}$ November, 293.

Jones, K.H. and Ennist, D.L. (1983). Immunomodulatory activities of Punarnavine 387. Rapid method for identification of macrophages in suspension by acid alphanaphthyl acetate esterase activity, J Histochem. C ytochem., 31:960-3.

Kaur, M. and Goel, R.K. (2009). Anti-Convulsant Activity of Boerhaavia diffusa: Plausible Role of Calcium Channel Antagonism. eC AM :1-7.

Khalid, M; Siddiqui, H.H. and Fareed, S. (2011). In vitro estimation of the antioxidant activity and phytochemical screening of B oerhaavia diffusa root extract. Asian J our nal of Traditional Medicines, 6:6.

Khandelwal, K.R. (2002). Practical Pharmacognosy, Techniques and Experiments. $9^{\text {th }}$ edition. Pune: Nirali Prakashan; 149-159.

Kirtikar, K.R. and Basu, B.D. (1956). Indian Medicinal Plants. Vol. III. 2nd ed. Lalit Mohan Basu, Allahabad, Uttar Pradesh, India. 2045-2048.

Kokate, C.K; Purohit, A.P. and Gokhle, S.B. (2005). Pharmacognosy. $38^{\text {th }}$ edn., Nirali Prakashan, Pune, India, p537-538.
Krishna, K.T; Ranjini, C.E. and Sasidharan, V.K. (1997). Antibacterial and antifungal activity of secondary metabolities from some medicinal and other common plant species. J . Life Sci., 2: 14-19.

Lamela, M; Cadavid, I; Gato, A. and Calleja, J.M. (1985). Effect of Lythrum saricaria in normoglycaemic rats, J Ethnopharm, (41):1-4.

Lami, N; Kadota, S; Kikuchi, T. and Momose, Y. (1991). Constituents of the roots of Boerhaavia diffusa L. III. .Identification of a Ca channel antagonistic compound from the methanol extract. Chemical and Pharmacological Bulletin, 39(6):1551-1555.

Mahesh ,A.R; Harish, K; Ranganath, M.K. and Devkar, R.A. (2012). Detail Study on Boerhaavia Diffusa Plant for its Medicinal Importance- A Review. Res. J. Pharmaceutical Sci, 1(1):28-36.

Meena, A.K., Niranjan, U.S., Yadav, A.K., Ajit, K., Singh, B. and Rao, M.M., (2010). A Quality Assessment of Boerhaavia diffusa Linn. Commonly Known as 'Punarnava' Plant. International J ournal of Pharmacognosy and Phytochemical Research, 2(1); 25-28.

Pandey, R; Maurya, R; Singh, G; Sathiamoorthy, B. and Naik, S. (2005). Immunosuppressive properties of flavonoids isolated from Boerhaavia diffusa. Int. I mmunopharmacol. 5(3): 541-553.

Pereira, D.M.; Faria, L. and Gaspar, P. (2009). Boerhaavia diffusa - Metabolte profiling of a medicinal plant from Nyctaginaceae. Food C hem. Toxicolo., 47:2142-49.

Rajpoot, K. and Mishra, R. N. (2011). Boerhaavia diffusa roots (Punarnava mool) - Review as Rasayan (Rejuvenator / Antiaging). International J ournal of Research in Pharmaceutical and Biomedical Sciences. 2 (4): 1451-1460.

Ramachandra,Y.L., Ashajyothi, C. and Rai, P. (2012). In Vitro Antibacterial Potential of Boerhaavia diffusa. IJ APBC, 1(3):420-424.

Rastogi, R.P. and Mehrotra B.N. (1993). Compendium of Indian Medicinal Plants. Lucknow and New Delhi: Central Drug Research Institute, Publications and Information Directorate. 2: 103 .

Satish, S; Raveesha, K.A. and. Janardhana, G.R. (1999). Antibacterial activity of plant extracts on phytopathogenic Xanthomonas compestris Pathovars. Letters in Applied Microbiology, 28:145-147.

Sazada, S; Verma, A; Rather, A.A; Jabeen, F. and Meghvansi, M.K. (2009). Preliminary phytochemicals analysis of some important medicinal and aromatic plants. Adv. in Biol. Res., 3:188-195.

Sumanth, M. and Mustafa, S.S. (2007). Antistress, Adoptogenic and immunopotentiating activity roots of Boerhavia diffusa in mice, International Journal of Pharmacology, 3(5): 416-420.

Trease, G.E. and Evans, W.C. (1989). Pharmacognosy. $13^{\text {th }}$ edn. Bailliere Tindall, London, 176-180pp.

Ujowundu, C.O; Igwe, C.U; Enemor, V.H.A; Nwaogu L.A and Okafor, O.E. (2008). Nutritive and Anti-Nutritive Properties of Boerhaavia diffusa and Commelina nudiflora Leaves. Pakistan J ournal of N utrition, 7(1): 90-92. 